International Journal of Social Science And Human Research

ISSN(print): 2644-0679, ISSN(online): 2644-0695

Volume 04 Issue 05 May 2021

DOI: $10.47191 / \mathrm{ijsshr} / \mathrm{v} 4-\mathrm{i} 5-02$, Impact factor-5.586

Page No : 876-878

\title{
Issues of Economic Development and Development of Intellectual Abilities in Education of Young People
}

\author{
Hamidjon Rozzakovich Matyakubov ${ }^{1}$, Ruzimboy Tulibaevich Abdullaev², Kholida Tulkunovna \\ Tulkinova $^{3}$ \\ ${ }^{1}$ Associate Professor, Urgench State University Uzbekistan \\ ${ }^{2}$ Master's Student, Urgench State University Uzbekistan \\ ${ }^{3}$ Lecturer, Tashkent State Pedagogical University Uzbekistan
}

ABSTRACT: This article describes how to improve the mental abilities of young people in the context of security and development of the state and analyzed the work of foreign education about the intellectual coefficient (IQ).

KEYWORDS: Education, Training, Technics, Technology, Information, Competition Mind, Coefficient.

\section{INTRODUCTION}

Today, economic competition between countries around the world is becoming competition between their education systems. It is known that today in the world there is a process of intensification, intellectualization, informatization of production processes. The competitiveness of products produced in the world market, especially non-raw materials, is determined by the extent to which they are enriched with intellectual content. This process is especially evident in the field of information and communication technologies, computers, mobile phones, home appliances, automotive, mechanical engineering, aviation and rocketry, and many other industries.

\section{THE MAIN RESULTS AND FINDINGS}

Reserve resources in Uzbekistan have a huge economic value. According to estimates in the Halq Sozi newspaper, Uzbekistan's current resource wealth (mineral and raw materials) is $\$ 970$ billion. [1].

The country's total mineral and raw material resources are estimated at 3.5 trillion soums. dollars. Mineral and raw material resources extracted from deposits and able to compete in the world market account for a quarter of GDP in the country, amounting to 5.5-6 billion annually. dollar wealth is being mined. Due to geological exploration, the value of field reserves is growing by $\$ 6-7$ billion annually. Establishing and developing production that can withstand such competition will place great challenges on the education system of any state. The fact is that in developed countries, well-educated people in all walks of life are doing a great job in the development and progress of the country, making up half of the employed part of society. The role of the intellect in the development of human civilization is growing not only under the influence of technological-industrial and economic factors, but also under the influence of social factors.

Today, developing countries see their future and power not only in increasing the number of people, but also in the growth of their intellectual potential. That is, they measure the growth of people's quality. In European countries, this IQ is measured by a test of the ability to acquire new knowledge and create new knowledge, and the ability of a person to achieve the goal set by logical thinking, the ability to find flaws in their work and find ways to overcome them and justify it.

It is useful to look at the results of research conducted by foreign scientists in this regard.

According to the results of research conducted by R. Linn and his colleagues, the national IQ of Russia and Ukraine - 97 points, Bulgaria and Bosnia - 90, Georgia - 94, Equatorial Guinea - 64, Estonia - 99, Israel - 95, India - 82, Ireland - 92, Spain 98, Italy - 102, Kazakhstan - 94, Canada - 99, Kyrgyzstan - 90, China - 105, Latvia - 98, Lithuania - 94, Macedonia - 94, Malta 97, the Netherlands - 100, Norway - 100, South Korea - 106, Poland - 99, Portugal - 95, Romania - 94, Serbia - 89, Singapore 108, Slovakia - 96, Slovenia - 96, USA - 98, Tajikistan - 87, Turkmenistan - 87, Turkey - 90, Uzbekistan - 87, Finland - 99, France - 98, Croatia - 90, Czech Republic - 98, Switzerland - 101, Sweden - 99, Japan - 105 [2].

According to the authors of the above research, the basis of the system that explains the quality and speed of civilizational development in different countries of the world is the intellect of the nation. If these studies were published in 2008, an analysis of the socio-economic changes that have taken place in the world to date shows that these views are less accurate. The 


\section{Issues of Economic Development and Development of Intellectual Abilities in Education of Young People}

global financial and economic crisis of 2008 affected all countries, testing not only their economic infrastructure but also their education systems. As a proof of this, it is enough to compare the growth of the country's GDP over the past 10 years and the results shown by our youth in international science olympiads and sports competitions with those of other countries. At the same time, it is necessary to continue the work on improving the intellectual abilities of young people in educational institutions and to find effective methods and tools and quickly implement them in practice.

In this regard, we find it necessary to quote the words of President Shavkat Miromonovich Mirziyoyev. "We all know that today is a time of high technologies and innovations. The developed countries of the world set themselves the task not only to produce many products and bring them to market, but also to transition to an innovative economy based on deep knowledge and scientific achievements. In other words, the development of its economy is becoming a key factor in development, not at the expense of existing natural resources, but through the creation, development and introduction of innovative products into production. Strategies and mechanisms of innovative development of the country are closely linked, first of all, with the effective use of the intellectual and scientific-technical potential created in this country" [3].

It would be expedient to work on the development of intellectual abilities of the youth of our country not only on the basis of the leadership of our republic, but also on the basis of international experience in this area.

U.S. scientists say the growth in intellectual capacity is 30 to 35 percent due to family lineage, 30 to 35 percent to water, iodine, and food therapy, and the remaining 30 to 35 percent to teachers and doctors.

Work is underway in our country in all three areas. Analysis of the concept of "national intelligence" shows that it occupies a leading position in my system of ideas, views that reflect the spiritual life of society. Along with the indicators of the IQ, it is necessary to analyze the indicators of the correct use of this ability in practice. Today there is a lot of non-fundamental research work in areas that are not relevant or economically justified, do not serve the development of sectors of the economy.

According to the researcher VV Orlov, the history of human intellect plays a key role in the development of human spirituality and culture. The formation and development of the nation's intellect is largely determined by the appropriate social structure, which depends on education, family, science and culture as social institutions. Education, which is a crucial area, plays a key role in this [4].

We have found it necessary to cite the views of three of the historical figures in this regard: 1) Otto von Bismarck stated that "wars are lost by the school teacher"; 2) Winston Churchill says that "a prime minister can only dream of a government with a teacher"; 3) Nobel Laureate American sociologist G. Becker proved that the basic education that increases the income of people and the state working in the field of human capital theory.

In less developed countries, highly skilled, intellectual labor is not valued. Often, scientists and professionals spend their time in simple physical labor and bureaucratic labyrinths. They do not understand that intellectual labor is more expensive. Therefore, innovations and technologies that can now be exported to EU countries in Arab and many African countries are almost non-existent. They do not teach their children to use new imported technologies. This, in turn, has a negative impact on the security of the state and the nation. Recent events in the Arab world are a clear example of this. Another conclusion is that the work to increase the intellectual potential of young people in our country should be carried out in conjunction with their spiritual and ideological upbringing.

The essence of the Jadid movement, which emerged after the occupation of Turkestan by Tsarist Russia, was to increase the intellectual abilities and worldview of the nation's youth and, as a result, to free it from colonial captivity.

\section{CONCLUSION}

Today, we consider it expedient to carry out the following work to increase the intellectual potential of young people in the field of education.

1. For the effective formation of human intelligence, it is necessary to develop in children memory, attention, curiosity, sense of novelty, depth of mind, flexibility, validity, logic, critical thinking and breadth, the ability to solve problems intuitively.

2. Preschools should be provided with toys that help children develop their intellect, taking into account their individual characteristics and age. An example of this is toys that have the ability to assemble and disassemble different constructions from pieces.

3. In families, it is advisable for parents to deal with their children with similar toys. Particular attention should be paid to the development of intellectual abilities in the education of children.

4. It is necessary to explain to young people studying in educational institutions the importance and essence of the IQ. In educating young people, it is necessary to choose from them the IQ that is higher than others and to deal with and encourage them as students with special talents.

5. Complexes of literature and didactic materials in educational institutions should be created in terms of increasing the intellectual potential of young people.

6. It is expedient to create measures and recommendations to increase the IQ and to introduce the widespread use of IQ tests in educational institutions by young people. 


\section{Issues of Economic Development and Development of Intellectual Abilities in Education of Young People}

The process of large-scale reforms currently underway in our country, such as building a strong civil society and a democratic state based on the rule of law, is inconceivable without the participation of young people, who make up the bulk of the population. After all, as the head of our state emphasized, today only highly educated, modern-minded, intellectually developed and professionally trained young people can be the most important condition and guarantee of quality, rapid and innovative development, which can ensure the great future of the country.

\section{REFERENCES}

1) Karimov I.A. High spirituality is an invincible force. - T .: "Spirituality", 2008.

2) Orlov V.V. The history of human intelligence / V.V. Orlov.- Perm: Publishing house of Perm. 1998.- 188 p.

3) Goziev E.G., Toshimov R.Yu. Methods of teaching psychology.-T .: NUUz printing house. 2005.-157 p.

4) Yakovets Yu.V. Globalization and interaction of civilizations / Yu.V. Yakovets. - M.: ZAO Publishing House "Economics", 2003. - 441 p. 